\title{
Pengaruh Lokasi dan Kreativitas Terhadap Keberhasilan Usaha Mikro Kecil Menengah (UMKM) di Kawasan Wisata Gentala Arasy Kota Jambi
}

\author{
Novita Ekasari dan Nurhasanah \\ Jurusan Manajemen Fakultas Ekonomi Dan Bisnis Universitas Jambi \\ Email: novitaekasari@yahoo.com; nur_hasanah@unja.ac.id
}

\begin{abstract}
ABSTRAK
Wirausaha diakui sebagai elemen kunci dalam pertumbuhan ekonomi danpenciptaan lapangan kerja. Agar keberhasilan perusahaan atau usaha yang diinginkan maksimal didalam berwirausaha harus didukung oleh kemampuan seorang pengusaha atau wirausaha itu sendiri yaitu kemampuan dalam hal pengetahuan, sikap, keterampilan, dan kematangan emosional. Salah satu kemampuan yang penting dimiliki oleh seorang wirausaha adalah kemampuan untuk menganalisis dan memprediksi suatu lokasi apakah tepat atau tidak untuk dijadikan sebagai tempat lokasi usaha. Penelitian ini bertujuan untuk melihat pengaruh Lokasi dan Kreativitas Terhadap Keberhasilan Usaha Mikro Kecil dan Menengah (UMKM) di Kawasan Wisata Gentala Arasy Kota Jambi. Sampel yang diambil dalam penelitian ini adalah 100 orang pelaku UMKM di Kawasan Gentala Arasy dengan teknik pengambilan data menggunakan kuesiner.dan perhitungan hasil menggunakan program SPSS. Hasil penelitian menunjukkan Secara Simultan Lokasi dan Kreativitas merupakan satu kesatuan dalam menciptakan Keberhasilan Usaha bagi para pelaku Usaha Mikro Kecil Menengah (UMKM) di Kawasan Gentala Arasy Kota Jambi. Lokasi dan Kreativitas berpengaruh secara simultan terhadap keberhasilan usaha dipengaruhi sebesar 65,5\% sedangkan sisanya sebesar 34,5\% dipengaruhi atau dijelaskan oleh variabel lain yang tidak dimasukkan dalam model penelitian ini. Secara parsial variabel yang memberikan pengaruh terbesar terhadap keberhasilan usaha adalah variable lokasi dengan pengaruh sebesar $66,53 \%$.
\end{abstract}

\section{Kata Kunci : Lokasi, Kreativitas, Keberhasilan Usaha}

\section{PENDAHULUAN}

Wirausaha diakui sebagai elemen kunci dalam pertumbuhan ekonomi dan penciptaan lapangan kerja. Agar keberhasilan perusahaan atau usaha yang diinginkan maksimal didalam berwirausaha harus didukung oleh kemampuan seorang pengusaha atau wirausaha itu sendiri yaitu kemampuan dalam hal pengetahuan, sikap, keterampilan, dan kematangan emosional. Salah satu kemampuan yang penting dimiliki oleh seorang wirausaha adalah kemampuan untuk menganalisis dan memprediksi suatu lokasi apakah tepat atau tidak untuk dijadikan sebagai tempat lokasi usaha, karena dalam berwirausaha factor lokasi merupakan salah satu factor yang sangat penting untuk dipertimbangkan sebelum seseorang memulai suatu usaha.

Selain Lokasi, pengusaha juga dituntut untuk memiliki kreativitas yang tinggidan inovasi yang baru dalam menunjang usahanya. Suryana (2008) mengatakan bahwa kreativitas adalah : "Berpikir sesuatu yang baru". Kreativitas sebagai kemampuan untuk mengembangkan ide-ide baru dan untuk menemukan cara-cara baru dalam memecahkan persoalan dan menghadapi peluang. Kreatif adalah kemampuan untuk mengembangkan ide-ide baru dan cara- cara baru dalam pemecahan masalah dan menemukan peluang (thinking new thing). Jadi, kreativitas 
adalah kemampuan untuk memikirkan sesuatu yang baru dan berbeda, Sesuatu yang baru dan berbeda tersebut dapat dalam bentuk hasil seperti barang dan jasa, dan bisa dalam bentuk proses seperti ide, metode, dan cara. Sesuatu yang baru dan berbeda yang diciptakan melalui proses berpikir kreatif dan bertindak inovatif merupakan nilai tambah (value added) dan merupakan keunggulan yang berharga. Nilai tambah yang berharga adalah sumber peluang bagi wirausaha. Ide kreatif akan muncul apabila wirausaha "look at old and thing something new or different". Setiap orang kreatif dalam tingkat tertentu, tetapi orang mempunyai kemampuan dan bakat dalam bidang tertentu dapat lebih kreatif dari pada yang lain maka dari itu diperlukan setiap individu mengasah kemampuannya untuk meningatkan kreativitas dari diri masing masing, setelah semua berjalan akan ada dampak hasil yang sangat berpengaruh terhadap usaha / bisnis yaitu akan muncul keberhasilan usaha. Ide akan menjadi peluang apabila wirausaha bersedia melakukan evaluasi terhadap peluang secara terus-menerus melalui proses menciptakan sesuatu yang baru dan berbeda, mengamati pintu peluang, menganalisis proses secara mendalam, dan memperhitungkan resiko yang mungkin terjadi. Untuk memperoleh peluang wirausaha harus memiliki berbagai kemampuan dan pengetahuan seperti kemampuan untuk menghasilkan produk atau jasa baru, menghasilkan nilai tambah baru, merintis usaha baru, melakukan proses atau teknik baru, dan mengembangkan organisasi baru. Untuk mencapai suatu keberhasilan usaha dalam berwirausaha dapat dilakukan dengan berbagai cara, salah satunya adalah dengan adanya seorang wirausaha yang kompeten dalam bidangnya, kebutuhan atau tujuan suatu usaha akan dengan mudah tercapai. Kota Jambi merupakan salah satu kota dimana sektor pariwisatanya masih sangat mungkin untuk tumbuh dan berkembang. Salah satu icon pariwisata baru yang banyak diminati oleh wisatawan local maupun domestic adalah kawasan wisata Gentala Arasy Meskipun masih terbilang baru, tempat ini merupakan salah satu tempat yang dijadikan ikon khas Kota Jambi. Dibangun di atas sungai Batanghari, Jembatan ini khusus dibuat sebagai tempat wisata untuk para penduduk dan juga pengunjung Kota Jambi. Jembatan ini sebenarnya baru saja dibangun pada pertengahan Tahun 2012, dan belum lama ini baru saja diresmikan oleh Wakil Presiden Indonesia, Bapak Jusuf kalla. Jembatan ini pada dasarnya terdiri dari dua buah bangunan ikonik yaitu Jembatan Pedestrian dan Menara Gentala Arasy, akan tetapi warga sekitar lokasi ini lebih sering menyebut jembatan ini Jembatan Gentala Arasy. Jembatan pedestrian merupakan jembatan yang membentang membentang di atas Sungai Batanghari. Jembatan ini memiliki bentuk berkelok-kelok seperti huruf S dengan panjang keseluruhan sekitar 530 meter. Jembatan ini sengaja dibangun sebagai tempat wisata untuk para pejalan kaki. Kendaraan bermotor tidak diijinkan melewati jembatan ini demi kepuasan para pejalan kaki. Di jembatan ini, Anda dapat berjalan-jalan sambil menikmati lalu lalang kapal yang ada di sungai Batanghari. Jika Anda ingin merasakan naik Kapal mengitari Sungai Batanghari, Anda dapat menyewa berbagai macam kapal yang ada di pinggiran Sugai Batanghari. Tidak hanya sekedar tempat wisata untuk berjalan kali menikmati pemandangan lalu lintas kapal di Sungai Batanghari, ketika malam hari Jembatan Gentala Arasy juga dijadikan salah satu pusat wisata kuliner di Kota Jambi. Anda dapat menemukan berbagai macam makanan ataupun olahan kuliner khas Kota Jambi di tempat ini. Wisata kuliner di Jembatan ini berlangsung dari sore hari hingga menjelang pagi dini hari. Di siang hari, para penjaja wisata kuliner dilarang berjualan di sekitar Jembatan ini. Tidak hanya makanan dan minuman yang banyak dijual di 
area sepanjang Gentala Arasy juga banyak pedagang yang menjual pernak pernik dan jasa permainan terutama bagi anak-anak yang tidak hanya menghibur tetapi juga membuat pengunjung memiliki beragam aktivitas pilihan selain hanya berjalan-jalan saja.

\section{METODE PENELITIAN}

Alur dalam penelitian ini menggunakan Diagram Tulang Ikan (Fishbone Diagram) yang akan menggambarkan jalan penelitian mulai dari apa yang akan dilakukan dalam penelitian, bagaimana cara melakukan penelitian, variable apa yang diteliti, dimana penelitian dilakukan sampai pada capaian yang akan dicapai dalam penelitian sesuai dengan jangka waktu penelitian yaitu 6 bulan.

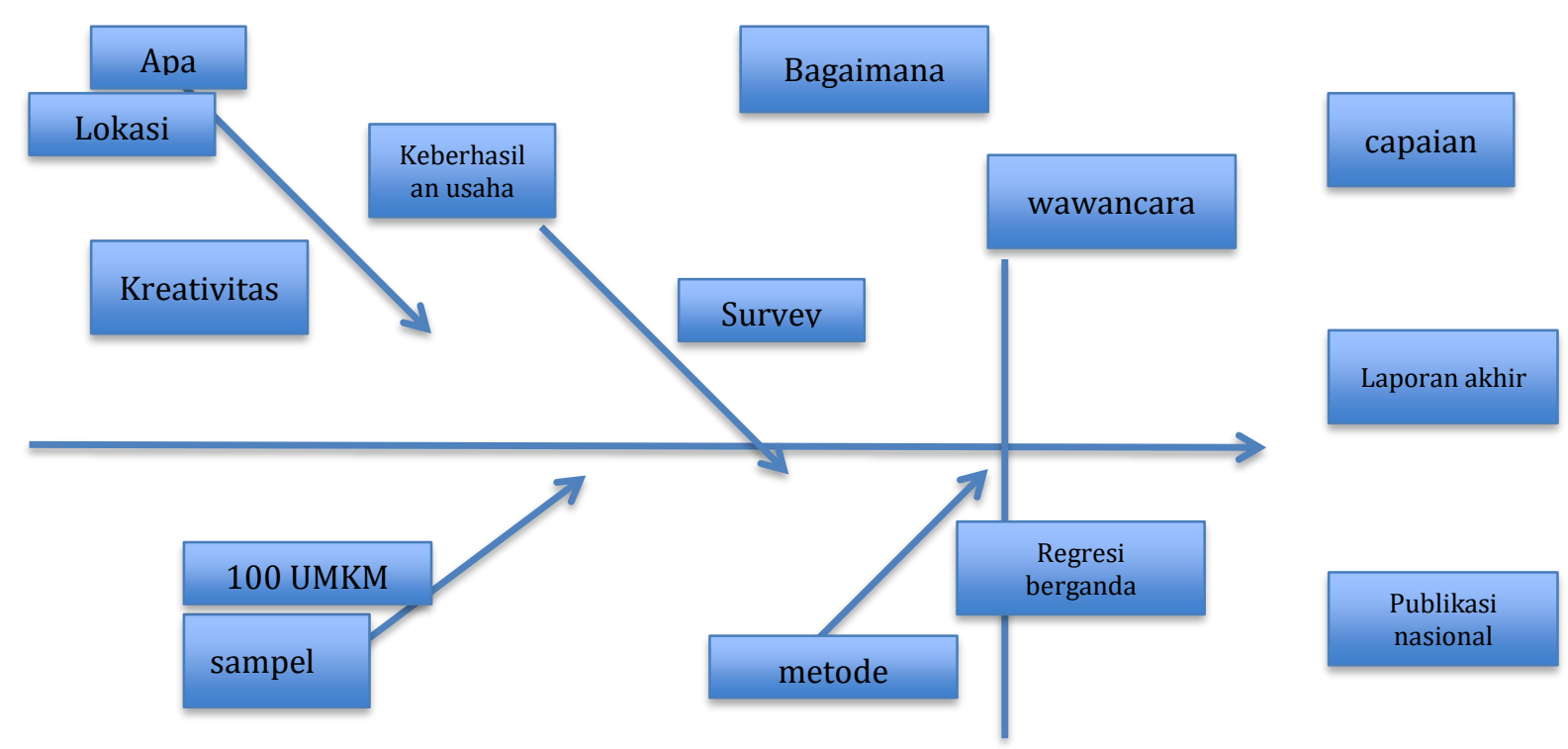

Gambar 1. Diagram Tulang Ikan (Fishbone Diagram)

Topik yang diteliti dalam penelitian ini adalah tentang pengaruh lokasi dan kreativitas para pelaku usaha (UMKM) terhadap keberhasilan usaha, penelitian dilakukan dengan mengambil sampel sebanyak 100 pedagang (UMKM) yang berjualan di kawasan wisata Gentala Arasy. Penelitian ini dilakukan dengan menggunakan metode survey dengan menggunakan kuesioner dan wawancara singkat untuk memperoleh data dengan para pelaku usaha. Adapun metode analisis data dengan menggunakan regresi berganda untuk melihat pengaruh dua variable atau lebih. Hasil capaian penelitian ini adalah laporan akhir dan publikasi nasional di jurnal sosio humanioran Lembaga Penelitian Dan Pengabdian Kepada Masyarakat (LPPM) Universitas Jambi.

\section{Jenis dan Sumber Data}

\section{Jenis Data}

Dilihat dari jenisnya penelitian ini tergolong penelitian survey dengan menggunakan pendekatan kuantitatif. Menurut Idrus (2009), penelitian kuantitatif lebih dimaksudkan untuk melihat fenomena yang ada, kemudian dibandingkan dengan teori yang dimiliki. Data dalam penelitian kuantitatif banyak didominasi oleh angka sebagai hasil dari suatu pengukuran berdasarkan pada variabel yang telah dioperasionalkan. 


\section{Sumber Data}

Sumber data adalah segala sesuatu yang dapat memberikan informasi mengenai data. Berdasarkan sumbernya, data dibedakan menjadi dua, yaitu data primer dan data sekunder.

1. Data primer yaitu data yang dibuat oleh peneliti untuk maksud khusus menyelesaikan permasalahan yang sedang ditanganinya. Data dikumpulkan sendiri oleh peneliti langsung dari sumber pertama atau tempat objek penelitian dilakukan.

2. Data sekunder yaitu data yang telah dikumpulkan untuk maksud selain menyelesaikan masalah yang sedang dihadapi. Data ini dapat ditemukan dengan cepat. Dalam penelitian ini yang menjadi sumber data sekunder adalah literatur, artikel, jurnal serta situs di internet yang berkenaan dengan penelitian yang dilakukan.

\section{Definisi Operasional dan Variabel}

Definisi operasional menjelaskan cara tertentu yang digunakan oleh peneliti dalam mengoperasionalkan construct, sehingga memungkinkan peneliti lain untuk melakukan pengulangan pengukuran dengan cara yang sama atau mencoba membagikan pengukuran construct yang lebih baik. Pada penelitian ini, definisi operasional dijabarkan dalam tabel berikut ini:

Tabel 1. Operasional Variabel Penelitian

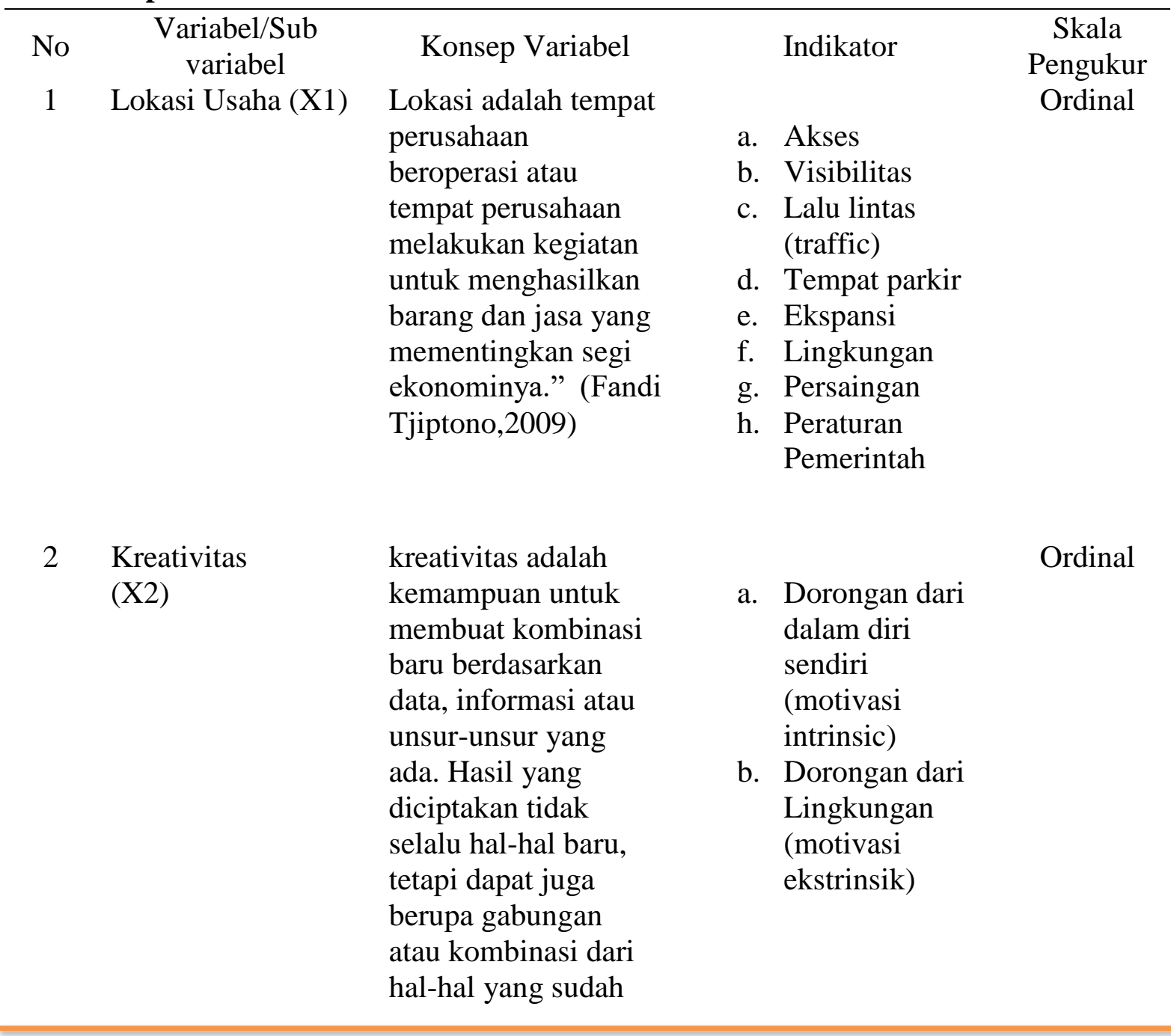




\begin{tabular}{|c|c|c|c|c|c|}
\hline & & $\begin{array}{l}\text { ada sebelumnya. } \\
\text { (Munandar, 2009) }\end{array}$ & & & \\
\hline 6 & $\begin{array}{l}\text { Keberhasilan usaha } \\
\text { (Y) }\end{array}$ & $\begin{array}{l}\text { Laba atau } \\
\text { keuntungan yang di } \\
\text { hasilkan, mampu } \\
\text { mensejahterakan } \\
\text { kehidupan } \\
\text { (Andreas,2011) }\end{array}$ & $\begin{array}{l}\text { a. } \\
\text { b. } \\
\text { c. } \\
\text { d. } \\
\text { e. }\end{array}$ & $\begin{array}{l}\text { Hasil cukup } \\
\text { untuk } \\
\text { memenuhi } \\
\text { kebutuhan } \\
\text { rumah tangga } \\
\text { Usaha bisa tetap } \\
\text { bertahan } \\
\text { Kesejahteraan } \\
\text { terjamin } \\
\text { Kesejahteraan } \\
\text { karyawan } \\
\text { terpenuhi } \\
\text { Dapat } \\
\text { berkembang }\end{array}$ & Ordinal \\
\hline
\end{tabular}

\section{Metode Pengumpulan Data}

Untuk mendapatkan data primer penulis menggunakan metode survei dengan memberikan pertanyaan - pertanyaan kepada responden dalam bentuk kuesioner. Dalam penelitian ini dipergunakan adalah kuesioner terstruktur yaitu kuesioner yang dilengkapi dengan alternatif jawaban dan responden memilih jawaban yang sesuai dengan persepsi atau pendapat responden.

Setiap jawaban responden diukur dengan skala Likert yaitu memberi 5 alternatif jawaban kepada responden sebagai berikut:

Skala 1 = sangat tidak setuju (STS)

Skala 2 = tidak setuju (ST)

Skala 3 = ragu-ragu $(\mathrm{RR})$

Skala $4=$ setuju $(\mathrm{S})$

Skala 5 = sangat setuju (SS)

Wirausaha yang menjadi responden dihubungi secara langsung di wilayah kawasan wisata Gentala Arasy dan diminta kesediaannya menjadi responden untuk pengisian koesioner yang akan dipandu oleh peneliti sendiri.

\section{Metode Analisis Data}

Dalam penelitian ini menggunakan metode analisis deskriptif. Analisis Deskriptif digunakan untuk menggambarkan variabel-variabel penelitian, yaitu Lokasi,Kreativitas dan keberhasilan usaha. Analisis deskriptif dilakukan untuk menyusun tabel frekuensi distribusi untuk mengetahui apakah tingkat perolehan nilai (skor) variabel yang diteliti masuk ke dalam kategori sangat baik/ sangat tinggi, baik/tinggi, cukup baik/cukup tinggi, tidak baik/rendah, dan sangat tidak baik/sangat rendah. 


\section{Uji Instrumen Penelitian}

\section{Uji Validitas}

Uji validitas digunakan untuk mengetahui sah atau valid tidaknya suatu kuesioner. Suatu kuesioner dikatakan valid jika pertanyaan pada kuesioner mampu untuk mengungkapkan kepuasaan perasaan wirausaha perabot rumah tangga tersebut. Uji validitas dilakukan dengan membandingkan nilai $\mathrm{r}$ hitung (correlated item-total correlations) dengan nilai $\mathrm{r}$ tabel. Jika nilai $r$ hitung > $r$ tabel dan bernilai positif maka pertanyaan tersebut dikatakan valid (Ghozali, 2006).

\section{Uji Realibilitas}

Reliabilitas adalah alat untuk mengukur suatu kuesioner yang merupakan indikator dari variabel atau konstruk. Suatu kuesioner dikatakan reliabel atau handal jika jawaban seseorang terhadap pertanyaan adalah konsisten atau stabil dari waktu ke waktu. SPSS memberikan fasilitas untuk mengukur reliabilitas dengan uji statistik Cronbach Alpha $(\alpha)$. Suatu variabel dikatakan reliabel jika memberikan nilai $(\alpha)$ 0,60 (Ghozali, 2006).

\section{HASIL DAN PEMBAHASAN}

Penelitian ini menganalisis pengaruh Lokasi (X1) dan Kreativitas (X2) terhadap Keberhasilan Usaha $(Y)$. Penelitian ini dilakukan di Kawasan Wisata Gentala Arasy Kota Jambi Jambi. Jumlah sampel yang diambil dalam penelitian ini berjumlah 100 orang. Adapun karakteristik responden meliputi Usia, Jenis Kelamin, Lama menjadi Pedagang dan Pendapatan per bulan.

\section{Usia}

Responden dikelompokkan berdasarkan usia dapat dilihat pada tabel di bawah ini:

Tabel 2. Karakteristik Responden Berdasarkan Usia

\begin{tabular}{ccc}
\hline Umur & Frekuensi & Persen \\
\hline 20-30 tahun & 41 & $41 \%$ \\
$31-40$ tahun & 55 & $55 \%$ \\
$\geq 40$ tahun & 4 & $4 \%$ \\
Total & $\mathbf{1 0 0}$ & $\mathbf{1 0 0 \%}$ \\
\hline
\end{tabular}

Sumber : Data Primer yang Diolah tahun 2017

Keterangan pada tabel 5.1 menunjukkan responden yang dikelompokkan berdasarkan usia 20-30 tahun sebanyak 41 orang atau 41\%, usia 31-40 tahun sebanyak 55 orang atau 55\%, dan di atas 40 tahun sebanyak 4 orang atau 4\%. Hal ini berarti responden pada kisaran usia 31-40 tahun lebih mendominasi dibandingkan responden pada kisaran usia yang lain.

\section{Jenis Kelamin}

Responden dikelompokkan berdasarkan jenis kelamin dapat dilihat pada tabel di bawah ini: 
Tabel 3. Karakteristik Responden Berdasarkan Jenis Kelamin

\begin{tabular}{lccc}
\hline \multicolumn{2}{c}{ Jenis Kelamin } & Frekuensi & Persen \\
\hline Laki-Laki & 65 & $45 \%$ \\
Perempuan & Total & 35 & $55 \%$ \\
& 100 & $\mathbf{1 0 0 \%}$ \\
\hline
\end{tabular}

Sumber : Data Primer yang Diolah tahun 2017

Keterangan pada tabel 5.2 menunjukkan responden terbanyak berjenis kelamin Laki-laki dengan jumlah 65 orang atau $65 \%$, sedangkan responden perempuan berjumlah 35 orang atau $35 \%$. Berdasarkan keterangan tersebut terlihat bahwa jumlah responden Laki-laki lebih mendominasi jika dibandingkan pada jumlah responden perempuan.

\section{Lama Menjadi Pedagang}

Responden dikelompokkan berdasarkan lama menjadi pedagang dapat dilihat pada tabel di bawah ini :

Tabel 4. Karakteristik Responden Berdasarkan Lama Menjadi Pedagang

\begin{tabular}{ccc}
\hline Lama Menjadi Pedagang & Frekuensi & Persen \\
\hline$<6$ bulan -1 Tahun & 25 & $25 \%$ \\
$1-1,5$ Tahun & 15 & $15 \%$ \\
$1,6-2$ Tahun & 20 & $20 \%$ \\
$\geq 2$ Tahun & 40 & $40 \%$ \\
\hline Total & $\mathbf{1 0 0}$ & $\mathbf{1 0 0 \%}$
\end{tabular}

Sumber : Data Primer yang Diolah tahun 2014

Keterangan pada tabel 5.3 menunjukkan bahwa responden yang dikelompokkan berdasarkan lama menjadi Pedagang $<6$ bulan - 1 tahun terdiri dari 25 orang atau 25\%, menjadi pedagang 1-1,5 tahun terdiri dari 15 orang atau $15 \%$ menjadi pedagang 1,5-2 tahun terdiri dari 20 orang atau $20 \%$ dan $\geq 2$ tahun 40 orang atau $40 \%$. Berdasarkan keterangan tersebut terlihat bahwa responden pada penelitian ini sebagian besar menjadi pedagang selama $\geq 2$ tahun.

\section{Pendapatan per Bulan}

Responden dikelompokkan berdasarkan pendapatan per bulan dapat dilihat pada tabel di bawah ini :

Tabel 5. Karakteristik Responden Berdasarkan Pendapatan per Bulan

\begin{tabular}{|c|c|c|}
\hline Pendapatan per Bulan & Frekuensi & Persen \\
\hline$<\operatorname{Rp} 500.000$ & 32 & $32 \%$ \\
\hline Rp 500.001 - Rp 1.000.000 & 24 & $24 \%$ \\
\hline $\operatorname{Rp} 1.000 .001-\operatorname{Rp} 4.000 .000$ & 19 & $19 \%$ \\
\hline$\geq \operatorname{Rp} 4.000 .000$ & 25 & $25 \%$ \\
\hline Total & 100 & $100 \%$ \\
\hline
\end{tabular}

Sumber : Data Primer yang Diolah tahun 2017 
Keterangan pada tabel 5.4 menunjukkan bahwa responden yang dikelompokkan berdasarkan pendapatan per bulan sebesar $\leq \mathrm{Rp} 1.500 .000-\mathrm{Rp} 2.000 .000$ terdiri dari 32 orang atau 32\%, pendapatan per bulan sebesar $\mathrm{Rp} 2.000 .000$ - Rp 3.000.000 terdiri dari 24 orang atau 24\%, pendapatan per bulan sebesar Rp 3.000.000 - Rp 4.000.000 terdiri dari 19 orang atau $19 \%$ dan pendapatan per bulan di atas Rp 4.000.000 25 orang atau 25\%. Berdasarkan keterangan tersebut terlihat bahwa responden pada penelitian ini sebagian besar pendapatan per bulannya sebesar $\leq$ Rp 1.500.000- Rp 2.000.000.

\section{Deskripsi Hasil}

\section{Tanggapan Responden}

Untuk memperoleh gambaran mengenai variabel Lokasi dan Kreativitas terhadap Keberhasilan Usaha, maka dapat diterangkan hasil deskriptif berupa tabel distribusi frekuensi sebagai berikut :

\section{Lokasi}

Lokasi yang salah, akan menyebabkan biaya operasi perusahaan tinggi. Oleh karena itu lokasi tempat usaha yang tepat merupakan tuntutan yang mutlak harus dipenuhi oleh setiap perusahaan. Variabel lokasi yang terdiri dari akses, visibilitas, Traffic, tempat parkir, ekspansi, lingkungan, persaingan dan peraturan pemerintah.

Hasil tanggapan responden mengenai pertanyaan yang diajukan seputar variable Lokasi disajikan pada tabel berikut:

Tabel 6. Tabulasi Tanggapan Responden Mengenai Lokasi

\begin{tabular}{clcccc}
\hline No. & \multicolumn{1}{c}{ Indikator } & N & Min & Max & Mean \\
\hline 1. & Jalan menuju lokasi baik & 100 & 2 & 5 & 4,41 \\
2. & Lokasi berjualan mudah dilihat & 100 & 3 & 4 & 4,34 \\
3. $\quad$ Tidak berada di daerah macet & 100 & 1 & 5 & 4,46 \\
4. $\quad$ Tempat parkir kendaraan luas & 100 & 3 & 5 & 4,43 \\
5. Mudah memperluas lapak/tempat & 100 & 3 & 5 & 4,52 \\
6. Lingkungan mendukung usaha & 100 & 2 & 5 & 4,22 \\
7. $\quad \begin{array}{l}\text { Banyak pesaing dengan usaha } \\
\text { sejenis }\end{array}$ & 100 & 3 & 5 & 4,43 \\
8. Peraturan pemerintah mendukung & 100 & 3 & 5 & 4,53 \\
\hline \\
Jumlah
\end{tabular}

Sumber : Data Primer yang diolah tahun,2017

Dimensi okasi terdiri atas delapan indikator. Nilai rata-rata dari masing-masing indikator dimensi ini disajikan dalam tabel 5.5. Dari tabel dapat disimpulkan, bahwa secara rata-rata persepsi responden terhadap pernyataan indikator-indikator dimensi Lokasi memiliki rata-rata 
sebesar 4,42. Angka ini menunjukkan bahwa secara rata-rata persepsi responden terhadap pernyataan-pernyataan pada indicator variable Lokasi adalah baik. Ini menunjukkan bahwa Lokasi Gentala Arasy sebagai tempat untuk berdagang dinilai baik dan menguntungkan oleh para pedagang itu sendiri.

\section{Kreativitas}

Kreativitas adalah kemampuan seseorang untuk menghasilkan suatu produk yang baru maupun kombinasi dari hal-hal yang sudah ada sebelumnya. Hasil tanggapan responden mengenai pertanyaan yang diajukan seputar Kreativitas disajikan pada tabel berikut:

Tabel 7. Tabulasi Tanggapan Responden Mengenai Kreativitas

\begin{tabular}{clcccc}
\hline No. & \multicolumn{1}{c}{ Indikator } & $\mathbf{N}$ & Min & Max & Mean \\
\hline 1. & $\begin{array}{l}\text { Menjadi kreatif karena banyak pengalaman } \\
\text { berjualan sebelumnya }\end{array}$ & 100 & 3 & 5 & 4,41 \\
2. $\begin{array}{l}\text { Mampu menilai kualitas barang sendiri yang } \\
\text { dijual }\end{array}$ & 100 & 3 & 5 & 4,34 \\
3. $\quad \begin{array}{l}\text { Suka bereksperimen dalam menjajakan jualan. } \\
\text { 4. } \quad 100\end{array}$ & 1 & 5 & 4,16 \\
Keluarga membantu dalam berjualan & 100 & 1 & 5 & 4,24 \\
6. & $\begin{array}{l}\text { Lingkungan tempat tinggal mendorong kreativitas } \\
\text { agar terlihat } \\
\text { berbeda. }\end{array}$ & 100 & 4 & 5 & 4,45 \\
\hline Jumlah & & & & & 4,34 \\
\end{tabular}

Sumber : Data Primer yang diolah tahun,2017

Dimensi Kreativitas terdiri atas 6 pernyataan. Nilai rata-rata dari masing-masing pernyataan dimensi ini disajikan dalam tabel 5.6. Dari tabel dapat disimpulkan, bahwa secara rata-rata persepsi responden terhadap pernyataan indikator-indikator dimensi kreativitas memiliki rata-rata sebesar 4,32. Angka ini menunjukkan bahwa rata-rata pedagang kecil yang berjualan di wilayah Gentala Arasy tersebut merespon baik terhadap dimensi kreativitas yang terdiri dari motivasi dari dalam diri dan motivasi dari luar diri yaitu lingkungan.

\section{Keberhasilan Usaha}

Hasil tanggapan responden mengenai pertanyaan yang diajukan seputar Variabel Keberhasilan Usaha disajikan pada tabel berikut:

Tabel 8. Tabulasi Tanggapan Responden Mengenai Keberhasilan Usaha

\begin{tabular}{clcccc}
\hline No. & \multicolumn{1}{c}{ Indikator } & N & Min & Max & Mean \\
\hline 1. & $\begin{array}{l}\text { Usaha tetap bisa bertahan dengan } \\
\text { penghasilan sekarang. }\end{array}$ & 100 & 3 & 5 & 4,53 \\
2. $\begin{array}{l}\text { Penghasilan cukup untuk kebutuhan } \\
\text { harian. }\end{array}$ & 3 & 5 & 4,52 \\
3danya peningkatan penghasilan dari & 100 & 3 & 5 & 4,50 \\
waktu ke waktu walaupun sedikit.
\end{tabular}




\begin{tabular}{llcccc}
\hline 4. Mampu membayar gaji karyawan atau & 100 & 2 & 5 & 4,34 \\
$\begin{array}{l}\text { yang membantu usaha. } \\
\text { 5. Yakin bahwa usaha ini dapat berkembang. }\end{array}$ & 100 & 3 & 5 & 4,51 \\
6. Bisa menabung walau sedikit untuk & 100 & 3 & 5 & 4,45 \\
$\quad$ perkembangan usaha dimasa depan. & & & & 4,48 \\
\hline Jumlah
\end{tabular}

Sumber : Data Primer yang diolah tahun,2017

Dimensi keberhasilan usaha terdiri atas lima indikator. Nilai rata-rata dari masing-masing indikator dimensi ini disajikan dalam tabel 5.8. Dari tabel dapat disimpulkan, bahwa secara rata-rata persepsi responden terhadap pernyataan indikator-indikator dimensi Keberhasilan Usaha memiliki rata-rata sebesar 4,48. Angka ini menunjukkan bahwa para pelaku usaha kecil merasa bahwa usaha mereka cukup memenuhi kebutuhan harian mereka dan yakin bisa mengembangkan usaha dimasa yang akan datang.

\section{Analisis Regresi Linier Berganda}

Regresi linier berganda digunakan untuk mengetahui pengaruh antara dua atau lebih variabel independen dengan satu variabel dependen. Persamaan yang digunakan adalah sebagai berikut :

$\mathrm{Y}=\mathrm{a}+\mathrm{b}_{1} \mathrm{X}_{1}+\mathrm{b}_{2} \mathrm{X}_{2}$

Berikut hasil pengujian regresi linier berganda yang disajikan pada tabel di bawah ini.

\section{Tabel 9. Hasil Regresi Linier Berganda}

\begin{tabular}{|c|c|c|c|c|}
\hline & Model & \multicolumn{2}{|c|}{$\begin{array}{l}\text { Unstandardized } \\
\text { Coefficients }\end{array}$} & \multirow{2}{*}{$\begin{array}{c}\text { Standardized } \\
\text { Coefficients } \\
\text { Beta }\end{array}$} \\
\hline & & $\mathrm{B}$ & Std. Error & \\
\hline \multirow[t]{4}{*}{1} & (Constant) & .708 & .279 & \\
\hline & Lokasi & & .085 & .565 \\
\hline & & .568 & & \\
\hline & Kreativitas & .291 & .081 & .304 \\
\hline
\end{tabular}

Berdasarkan keterangan pada tabel maka diperoleh persamaan regresi sebagai berikut :

$$
\mathrm{Y}=0,708-0,568 \mathrm{X}_{1}+0,291 \mathrm{X}_{2}
$$

Berdasarkan persamaan regresi linier tersebut dapat diinterpretasikan sebagai berikut:

1. Konstanta (a) $=0,708$

Ini berarti jika semua variable independen (lokasi dan kreativitas) dianggap sama dengan nol (0) maka nilai variable dependen (keberhasilan usaha) sebesar 0,708.

2. Lokasi Usaha $(\mathrm{X} 1)=0,568$

Nilai koefisien Lokasi Usaha (X1) bertanda positif terhadap Keberhasilan Usaha dengan nilai koefisien regresi sebesar 0,568 . Hal ini menunjukkan bahwa setiap nilai variable 
Lokasi Usaha dinaikan sementara variable kreativitas diasumsikan tetap, maka variable Keberhasilan Usaha (Y) akan meningkat sebesar 0,568.

3. Kreativitas (X2)

Niali koefisien Kreativitas (X2) bertanda positif terhadap Keberhasilan Usaha dengan nilai koefisien regresi 0,291. Hal ini menunjukkan bahwa setiap nilai variable Lokasi Usaha diasumsikan tetap maka variable keberhasilan usaha (Y) akan meningkat sebesar 0,291 .

\section{Uji Hipotesis}

\section{Uji F}

Uji F digunakan untuk menunjukkan apakah semua variabel independen atau bebas yang dimasukkan dalam model mempunyai pengaruh secara bersama-sama terhadap variabel dependen/terikat (Ghozali, 2011).

Berikut merupakan hasil uji F yang disajikan pada tabel di bawah ini:

\section{Tabel 10. Hasil Uji F}

\begin{tabular}{|c|c|c|c|}
\hline \multicolumn{4}{|c|}{ ANOVA $^{b}$} \\
\hline Model & & $\mathrm{F}$ & Sig. \\
\hline 1 & Regression & 92.184 & $.000^{\circ}$ \\
\hline & Residual & & \\
\hline & Total & & \\
\hline
\end{tabular}

a. Predictors: (Constant), Lokasi,kreativitas

b. Dependent Variable: KeberhasilanUsaha

Sumber : Hasil Pengolahan Data Tahun 2017

Berdasarkan tabel terlihat bahwa nilai $\mathrm{F}_{\text {hitung }}$ sebesar 92,184 dengan $p$-value sebesar 0,000 dan nilai $F_{\text {hitung }}$ lebih besar dari nilai $F_{\text {tabel }}(92,184$ > 2,47). Dengan demikian H0 ditolak dan menerima Ha. Dari hasil tersebut dapat dinyatakan bahwa secara simultan Lokasi dan Kreativitas berpengaruh terhadap Keberhasilan Usaha.

\section{Koefisien Determinasi $\left(\mathbf{R}^{2}\right)$}

Analisis koefisien determinasi disesuaikan dan digunakan untuk mengetahui seberapa besar presentase variabel independent $(\mathrm{X})$ terhadap dependent $(\mathrm{Y})$ dalam bentuk presentase.

Berikut merupakan hasil pengujian koefisien determinasi yang disajikan pada tabel di bawah ini :

Tabel 11. Koefisien Determinasi

\begin{tabular}{|c|c|c|c|c|}
\hline \multicolumn{5}{|c|}{ Model Summary } \\
\hline Model & $\mathrm{R}$ & R Square & $\begin{array}{l}\text { Adjusted R } \\
\text { Square }\end{array}$ & $\begin{array}{l}\text { Std. Error of the } \\
\text { Estimate }\end{array}$ \\
\hline 1 & $.809^{\mathrm{a}}$ & .655 & .648 & .26947 \\
\hline
\end{tabular}

a. Predictors: (Constant), lokasi,kreativitas

b. Dependent Variable: Keberhasilan_usaha

Sumber : Hasil Pengolahan Data Tahun 2017 
Berdasarkan tabel di atas diperoleh angka $R$ Square sebesar 0,655 atau 65,5\%. Hal ini menunjukkan Lokasi dan Kreativitas berpengaruh secara simultan terhadap keberhasilan usaha dipengaruhi sebesar $65,5 \%$ sedangkan sisanya sebesar $34,5 \%$ dipengaruhi atau dijelaskan oleh variabel lain yang tidak dimasukkan dalam model penelitian ini.

\section{Uji t}

Uji t dilakukan guna mengetahui apakah variabel independent (Lokasi dan Kreativitas) berpengaruh secara parsial terhadap variabel dependen (Keberhasilan Usaha). Berikut merupakan hasil uji t yang disajikan pada tabel di bawah ini :

\section{Tabel 12. Hasil Uji t}

Model

1
(Constant)

Lokasi

Kreativitas $\mathrm{t}$

Sig.

2.358

.013

6.653

.000

3.582

.001

\section{Dimensi Lokasi $\left(\mathrm{X}_{1}\right)$}

Terdapat pengaruh yang signifikan pada dimensi Lokasi terhadap customer Keberhasilan Usaha. Dari hasil pengujian diperoleh untuk variabel $\mathrm{X}_{1}$ diperoleh level signifikansi sebesar 0,000 $(<0,05)$ dan berarah positif. Dari hasil tersebut dapat dinyatakan bahwa secara parsial Lokasi berpengaruh terhadap customer Kebeerhasilan Usaha.

2. Dimensi Kreativitas $\left(\mathrm{X}_{2}\right)$

Terdapat pengaruh yang signifikan pada dimensi kreativitas terhadap Keberhasilan Usaha. Dari hasil pengujian diperoleh untuk variabel $\mathrm{X}_{2}$ diperoleh level signifikansi sebesar 0,001 $(<0,05)$ dan berarah positif. Dari hasil tersebut dapat dinyatakan bahwa secara parsial kreativitas berpengaruh terhadap Keberhasilan Usaha.

\section{Implikasi Hasil}

Saat ini tingginya tingkat persaingan di kawasan wisata gentala arasy membuat para pelaku usaha kecil menengah harus memperhatikan situasi persaingannya. Salah satu cara yaitu dengan memperoleh keunggulan yang kompetitif melalui kreativitas yanitu melakukan sesuatu yang baru atau berbeda dari para pelaku usaha lain dikarenakan rata-rata pedagang menjual barag dagangan maupun jasa yang hampir sama sehingga jika pelaku usaha tidak melakukan hal yang berbeda maka pelanggan tidak akan bisa memilih lapak mereka sebagai alternative pertama pilihan pelanggan.

Penelitian ini telah menganalisis pengaruh Lokasi dan Kreativitas terhadap Keberhasilan Usaha pada Usaha Mikro Kecil dan Menengah (UMKM) di kawasan wisata Gentala Arasy Jambi. Hasil penelitian menunjukkan bahwa pengaruh dimensi Lokasi terhadap Keberhasilan Usaha saling terkait dengan kerangka konseptual penelitian yang dibuktikan dari hasil kecocokan beberapa model yang signifikan.

Dengan demikian Para pelaku UMKM di Kawasan wisata Gentala Arasy Jambi agar dapat melakukan sesuatu yang berbeda yang diberikan kepada konsumennya, yaitu dengan 
memperhatikan dan memanfaatkan lebih lanjut aspek-aspek indikator variabel Lokasi dan Kreativitas yang terdiri dari:

\section{Lokasi}

Variabel Lokasi yang terdiri dari indicator-indikator Akses, Visibilitas, Traffic, Tempat Parkir, ekspansi, lingkungan, persaingan dan peraturan pemerintah, Merupakan kemudahan pelanggan untuk mencapai para pedagang dimana di kawasan ini karena kendaraan dilarang melintas di kawasan wisata sehingga akses pelanggan adalah melalui berjalan kaki bagi pedagang yang berjulalan di ujung dan dalam menara sedagkan bagi yang bejualan dibawah jembatan Gentala Arasy akses bisa dilalui oleh kendaraan. Letak kawasan wisata yang ditengah kota memudahkan masyarakat yang merupakan pelanggan utama mudah untuk mencapai lokasi ini. Hasil menunjukkan bahwa bagi pedagang masyarakat yang datang terus bertambah banyak dikarenakan kawasan wisata ini berda pada jalan yang ramai dan merupakan kawasan wisata kota yang cukup diminati oleh masyarakat. Kawasan wisata yang berada dijalan utama bisa dilihat dari arah manapun menunjukkan visibilitas lokasi cukup baik, tempat parkir dan ekspansi merupakan indicator yang kurang baik karena untuk kendaraan roda empat tempat parkir dipinggir jalan dan belum memiliki tempat khusus begitu juga persaingan cukup tinggi karena ratarata penjual menjual barang atau jasa yang hampir sama. Keyakinan untuk bisa melakukan ekspansi atau perluasan lapak dirasakan oleh para pedagang walaupun agak sulit karena kawasan wisata yang memiliki lahan untuk berjualan yang dirasakan terbatas. Sedangkan Peraturan pemerintah daerah dirasakan cukup mendukung usaha yang dilakukan oleh pelaku usaha UMKM, sehingga secara keseluruhan dapat dikatakan Lokasi memiliki pengaruh yang signifikan terhadap Keberhasilan Usaha Para Pelaku UMKM di Kawasan Wisata Gentala Arasy ini.

\section{Kreativitas}

Merupakan kemampuan para pelaku usaha untuk memperoleh motivasi untuk melakukan sesuatu yang baru atau berbeda. Motivasi ini hendaknya mampu dimanfaatkan pedagang untuk menarik lebih banyak pelanggan dengn menjajakan dagangan yang lebih bervariasi atau beragam. Diperoleh hasil dari penelitian bahwa para pedangang kadang suka bereksperimen dalam menjajakan dagangannya walaupun mungkin belum terlalu terlihat perbedaannya. Hasil paling tinggi menunjukkan dari sisi kreativitas ternyata masukan dari keluarga justru paling berpengaruh tinggi terhadap sisi kreativitas dari para pedagang karena mungkin dikarenakan mereka lebih banyak dibantu oleh anggota keluarga dibandingkan orang lain (karyawan) dikarenakan keterbatasan penghasilan, walaupun demikinan baik per indicator maupun secara keseluruhan respon para responden baik terhadap dimensi kreativitas sehingga dapat dikatakan dimensi kreativitas berpengaruh signifikan terhadap keberhasilan usaha.

Untuk mencapai keberhasilan usaha banyak faktor yang mempengaruhinya, dimana diantaraya adalah penetuan lokasi usaha dan daya kreativitas dari para pelaku usaha itu sendiri.. Dari hasil penelitian ini dapat disimpulkan bahwa Variabel lokasi yang terdiri dari , Akses, Visibilitas, Traffic, Tempat Parkir, ekspansi, lingkungan, persaingan dan peraturan pemerintah serta variable kreativitas yang terdiri dari pengaruh instrinsik dan ekstrinsik berpengaruh secara simultan terhadap keberhasilan usaha para pelaku usaha Mikro Kecil 
Menengah (UMKM) yang berada di Kawasan Wisata Gentala Arasy Jambi., dengan nilai $R$ square $65,5 \%$, sedangkan 34,5\% dipengaruhi variabel lain yang tidak diteliti.

\section{Luaran}

Luaran yang ingin dicapai dalam penelitian ini adalah publikasi ilmiah berupa jurnal nasional terakreditasi yaitu jurnal sains sosio humaniora vol. 2 juni 2018 Lembaga Penelitian dan Pengabdian Kepada Masyarakat Universitas Jambi.

\section{Kesimpulan}

\section{KESIMPULAN DAN SARAN}

Berdasarkan hasil penelitian dan pembahasan yang diuraikan pada Bab $\mathrm{V}$, maka dapat diambil beberapa kesimpulan sebagai berikut:

1. Secara Simultan Lokasi dan Kreativitas merupakan satu kesatuan dalam menciptakan Keberhasilan Usaha bagi para pelaku Usaha Mikro Kecil Menengah (UMKM) di Kawasan Gentala Arasy Kota Jambi. Lokasi dan Kreativitas berpengaruh secara simultan terhadap keberhasilan usaha dipengaruhi sebesar 65,5\% sedangkan sisanya sebesar 34,5\% dipengaruhi atau dijelaskan oleh variabel lain yang tidak dimasukkan dalam model penelitian ini.

2. Secara parsial variabel yang memberikan pengaruh terbesar terhadap keberhasilan usaha adalah variable lokasi dengan pengaruh sebesar $66,53 \%$.

\section{Saran}

Berdasarkan kesimpulan penelitian maka penulis mencoba memberikan masukan atau pertimbangan berupa saran-saran sebagai berikut :.

- Bagi para pelaku UMKM khususnya dikawasan gentaa Arasy dapat memahami bahwa factor lokasi dan kreativitas merupakan factor penting bang keberhasilan usaha mereka sehingga mereka dapat menjadi lebh serius dalam berwirausaha dan mencoba untuk bisa menjadi lebih kreatif serta memanfaatkan peluang yang timbul dari strategisnya lokasi usaha mereka.

- Diharapkan penelitian ini dapat menjadi dasar untuk penelitian selanjutnya dan variable dapat dikembangkan atau diperdalam lagi.

- Luaran dapat berupa sesuatu model program pelatihan kreativitas yang nyata atau inspirasi inovasi bagi para pelaku usaha mikro di Kawasan Wisata Gentala Arasy.

\section{DAFTAR PUSTAKA}

Aliaras Wahid, Mudjiarto. 2006. Membangun Karakter Dan Keperibadian Kewirausahaan. GRAHA ILMU, Yogyakarta.

Alma, Buchari. 2005. Kewirausahaan Untuk Mahsiswa Dan Umum. PT ALFABETA, Bandung.

Arikunto, Suharsimi. 2006. Prosedur Penelitian Suatu Pendekatan Praktik,Jakarta : Rineka Cipta

Fandy Tjiptono. 2002. Strategi Pemasaran. Yogyakarta : Andi offset. 
Jurnal Sains Sosio Humaniora

Volume 2 Nomor 1 Januari - Juni 2018

Harefa, Andrias. 2007. Inovasi Kewirausahaan: Kecerdasan Emosi Wirausaha. Diakses tanggal 15 Februari 2007. (www.pembelajar.com)

Hadian, Hendrik. 2010. Peranan Perilaku Kewirausahaan Dampaknya Terhadap Keberhasilan Usaha. Skripsi.

Munandar. 2009. Kreativitas sepanjang Masa .Jakarta : Pustaka sinar harapan prawirokusumo

Suryana. 2008. Kewirausahaan : Pedoman Praktis : Kiat dan Proses menuju sukses. Jakarta. Penerbit Salemba Empat.

Suharsimi. 2010. Prosedur penelitian suatu pendekatan praktik. Jakarta: Rieni Cipta . 